DOI: https://doi.org/10.31933/dijemss.v2i3

Received: $25^{\text {th }}$ November 2020, Revised: $15^{\text {th }}$ January 2021, Publish: $4^{\text {th }}$ March 2021

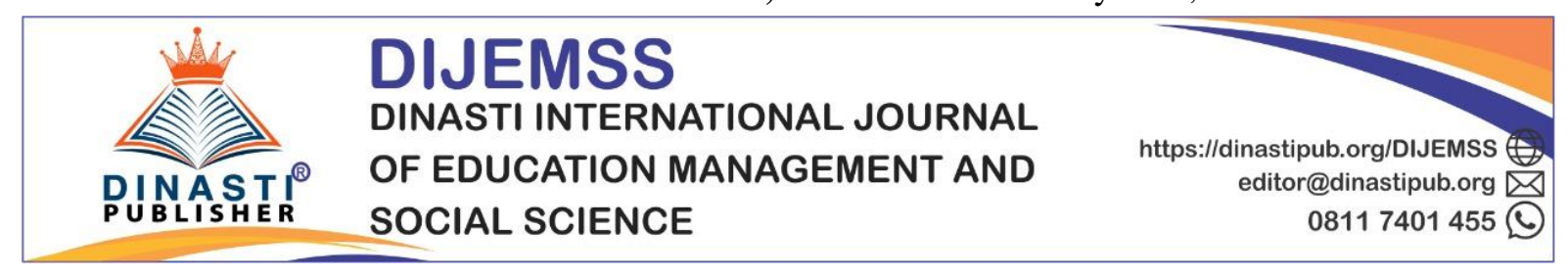

\title{
ROLE OF ORGANIZATIONAL COMMUNICATION IN CBT PLANNING PROCESS FOR PABUARAN VILLAGE AS RELIGIOUS TOURISM
}

\author{
Patricia Robin ${ }^{1}$, Maria Bianda ${ }^{2}$, Amanda Kristanti ${ }^{3}$ \\ ${ }^{1)}$ Universitas Bunda Mulia, Jakarta, Indonesia, probin@bundamulia.ac.id \\ ${ }^{2)}$ Universitas Bunda Mulia, Jakarta, Indonesia, mbianda@bundamulia.ac.id \\ ${ }^{3)}$ Universitas Bunda Mulia, Jakarta, Indonesia
}

Corresponding author: Patricia

\begin{abstract}
Communication is very important in human life, especially in organizations. Certainly, organizationl behaviour involves communication. Without communication within the organization, organizing effort may not run smoothly. The researcher will raise how organizational communication occurs between the government and the people of Pabauran Village to improve its the tourism. In this research, a qualitative method which involved an interpretation process on the condition of the natural subject is used. The strategy of this case study leads to derivative social units with steps starting from collecting data with active participant observation and interviews, then analyzing the organizational communication relationship within the organization in its management with the Village Officials, data processing, and analysis that produces conclusions. The results obtained were Community Based Tourism (CBT) which is a village that has a culture of harmony between religious communities is needed through implementation of downward communication within the managing officials.
\end{abstract}

Keywords: Organizational Communication, Tourism Village, CBT

\section{INTRODUCTION}

Indonesian tourism nowadays is growing in its various regions, including rural villages, where this sector helps the economic equality process and increases community welfare. A model of tourism development which The Ministry of Tourism has been promoting is called "Desa Wisata" or Tourism Village. This model prioritizes in increasing the villages' potential resources to create positive impacts for the community. The concept application of Community Based Tourism (CBT) aims to help local communities including rural villages to develop without losing their authentic identity (Ahsani, Suyaningsih, Ma'rifah \& Aerani, 2018).

Pabuaran Village is located in Gunung Sindur District, Bogor, West Java. It is adjacent to the South Tangerang City, Banten Province. This village is the gate for visitors to enter West Java Province. Pabuaran Village is rich in harmony and diversity, where four 
religions, namely Islam, Christianity, Buddhism, and Confucianism live in harmony and tolerance.

In 2017, Pabuaran Village potential was explored by the Government of West Java Province. It was selected as one of 19 villages in West Java Province to be part of West Java's "Emas (Gold) Village" pilot project. According to the West Java Provincial Government, Emas Villages (2016) are expected to be independent, flourished, and prosperous in the management of their resources and economy.

Communication as an applied science shows in every aspect of human life, whether as an individual or a social being. Communication has a fundamental meaning, namely how communicators give messages to communicants with the help of the media. It then provide feedback, as well as any disturbances or consequences. Apparently this concept also emerge in the Pabuaran Village, which is planning its way to become a Tourism Village with local wisdom contained in religious nuances.

The main focus is that governing organizations cannot carry out the purposes of resources and even achieve its goals without communication activities. Communication will also lead to accelerate development with minimal risk of obstacles, when optimal communication is carried out. Therefore this is the main focus of the researcher when the Tourism Village is not a product but a process of work from the local government, which requires both internal and external communication process .

In-depth understanding of organizational communication helps internal or external stakeholders to take action in developing the potential of a tourism village. Community and government have a big role to play in this effort.

The objectives of this study are:

1. To analize the potential of Pabuaran Village as a Religious Tourism Village.

2. To understand the relationship between village institutional communication and community involvement in the planning process for CBT in Pabuaran Village as a religious tourism village.

A tourism village is a form of community which optimizes the village's local resources while maintaining local wisdom. This is likely to have a positive impact on the sustainability of residents, regional and central government as a positive image is increasingly formed. Organizational communication is the key, because it is not only discuss hierarchical issues, but also the relationship between the personas of each actor in it.

\section{LITERATURE REVIEW Community Based Tourism}

Community Based Tourism (CBT) is a concept to maximize the positive impact of economic growth, social welfare, maintenance of local culture, and empowerment of a community's nature, by actively involving the people of the region (ASEAN, 2016). This concept focuses on empowering community businesses and small communities to develop their domicile areas using their unique resources. The criteria to be met in order to help meet the standards of this concept are:

1. Communication and transparent management in community welfare development 
2. Build cooperation between the parties who participate in building the community

3. Obtain recognition from the local government

4. Improve the social welfare of local residents

5. Have a profit sharing mechanism which is transparent and fair to its residents

6. Contribute to the local and regional economy

7. Respect the traditions and culture of local residents from generation to generation

8. Contribute directly to the preservation of local nature

9. Increase the positive experiences which visitors receive from local residents

10. Residents continue to improvise to become financially independent

The standards above are applied, hence visitors get physical and psychological satisfaction while visiting the area, while local residents can improve their quality of life through sustainable economic, social and natural benefits (ASEAN, 2016).

\section{Tourism Village}

Indonesian tourism has developed to support the economy of societies in Indonesia, including communities who live in rural areas. The Ministry of Tourism of the Republic of Indonesia (2019) stated that the village has a variety of potentials that need to be explored to develop the area into a new tourist area that is able to provide new livelihoods for its citizens. A tourist village was formed with the aim of attracting visitors with the uniqueness of the area through direct participation from the community. Villagers play a role hosts who actively participate in developing the potential of their area to improve their standard of living.

There are several criteria that need to be considered in the process of developing a tourist village according to Hadiwijoyo (2012), namely: supporting accessibility for visitors, having a unique tourist attraction that has the potential to become a new attraction, full support for village development and tourist acceptance, a security system that guarantees both residents and tourists in the area and adequate facilities are available for the scope of accommodation, telecommunications, and human resources for service providers.

Triambodo and Damanik (2019) argue that village's government has an important role in the process towards the independence of a tourism village. This institution shall function as a medium to facilitate and mobilize residents to participate in the expansion of a tourism village (Putra, Aryanti, Astina, \& Setiawan, 2019).

\section{Tourism Village Potential Development}

Within the scope of developing a tourism village in the long term, readiness is needed from both the community and local government. Syafi'i and Suwandono (2015) describe the steps of a tourism village development strategy, starting from

1. Involve local communities from the planning stage to the results evaluation stage.

2. Development of tourism village potential based on its uniqueness

3. Formation of community organizations as the main driving force for tourism villages.

4. The involvement of local governments in the framework of fostering and supporting the regions.

5. Initial assistance regarding the potential of tourism villages to the community 
6. Training to increase the knowledge and ability of residents to support tourism villages

7. Providing regular education to increase awareness of new information.

\section{Organizational Communication}

Understanding how humans organize is a form of the application of Karl Weick's Theory, in which he makes communication the basis of human organizing. In his presentation, he said that an organization is not an arrangement formed by position and role, but by the communication activity itself. Organizations exist and are formed due to interactions, so human behavior is linked due to the dependence of one behavior to another (Littlejohn \& Foss, 2009).

Organizational activities function to reduce information uncertainty or a state of equivocality, which means uncertainty, difficulty, ambiguity, and a lack of predictability. All information from the environment is considered to be vague or ambiguous at some level. In this case, organizational activities are designed to reduce the lack of uncertainty. The level of equivocality experienced differs in each situation, but is often quite large, so reducing it requires major organizational implications (Littlejohn \& Foss, 2009).

In this case, researchers will focus on how the form of communication within government agencies as a process of sharing information, ideas, ideas or feelings, and attitudes among government officials which are used for internal purposes (downward communication and upward communication) and or external to the organization (Hasan, 2007).

Communication in the organization takes place in various forms of relations namely between personas, positional, superior-subordinate, to a sequence. In fact, in government communication, with the existence of hierarchies and more detailed rules, the last three types of relationships are more pronounced than interpersonal matters. For example, there is a superior-subordinate relationship which shows how positions are arranged in a hierarchical order, so that the ongoing communication process follows; followed by a positional relationship by the authority structure and functional duties of members. Finally, there is a serial relationship which shows how information is conveyed throughout the formal organization through a process, in which the party at the top of the hierarchy sends a message to then be conveyed again to a third party (Pace \& Faules, 2010).

In the presentation of Pabuaran Village, researchers also highlighted government communication, which consists of executives or government officials who influence the attitude, understanding, and behavior of the bureaucracy and society. Every element involved in the administration of democratic governance is part of the government communication process in a position that can be as a sender or at other times as a receiver. Government officials or bureaucrats who want to achieve common goals as expected, are strongly advised to understand various communication events that often occur in organizations, such as receiving messages, understanding messages, and how messages are implemented correctly (Silalahi, 2004).

Interdependence between networks then becomes the main point in this case, namely when the flow of delivery and reception of messages through the network is interdependent in nature based on formal rules. When this happens, the message that appears is not only 
information, but also the dissemination of ideas, instructions, and / or feelings related to government actions and policies (Malone in Silalahi, 2004; Harris, 2002).

\section{RESEARCH METHODS Qualitative Research}

In obtaining and analyzing the data, the research methodology used in this study is a qualitative approach, which involves an interpretation process on natural subject conditions. This study seeks answers to how social experiences are created and provide meaning. This research prioritizes social construct facts or facts, recognizes the closeness of the relationship between the researcher and the problem, as well as the situations that force the research to be held (Denzin \& Lincoln, 1994).

Furthermore, case studies are a strategy chosen by researchers because they will carefully investigate an event, program, activity, process, or group of individuals whose cases are limited by time and activity. This study is comprehensive, intense, detailed, and in-depth and is directed as an effort to examine problems or phenomena that are contemporary or present. Throughout the study, researchers collected complete information using data collection procedures based on a predetermined time. In terms of its coverage area, case research covers a narrow area or subject; In terms of its nature, this study prioritizes depth (Bungin, 2003: 20).

For the record, the case studies conducted by researchers will look at the life of organizations or individuals who are used as units of analysis (members of organizations and residents of Pabuaran Village) in the steps towards the Independent Religious Tourism Village. This case study strategy leads researchers to enter the smallest social units with steps starting from collecting data with active participant observation and interviews, then analyzing the organizational communication relationship in relation to the Village Council, followed by data processing and analysis that produces conclusions.

In obtaining data, researchers need resource persons who contribute by answering questions in the in-depth interview session. The research resource person plans are representatives of the West Java Provincial Government who are promoting the Emas Village program, representatives of the village government or the Pabuaran Village Agency, residents who contribute and / or choose not to contribute Pabuaran Village to become an Independent Religious Tourism Village.

Every resource person who is willing to be interviewed in-depth (in-depth interview) must have the knowledge and ability to provide neutral or impartial information that will develop the research repertoire. Capability and credibility play an important role in this case, when the source become the informant and / or key informant.

In presenting the results, the researcher prioritizes the analysis of the results using James Spradley's descriptive approach, specifically from the third category, namely standard ethnography which shows the level of diversity in the use of native languages. This description raises the informant's conception and includes terms from the indigenous population. The concepts and meanings possessed by the informants are included in the description and provide an in-depth understanding of the other views of life that are owned by the community itself. 


\section{FINDINGS AND DISCUSSION \\ Religion Based Pabuaran Village}

The researcher succeeded in exploring deeper into Pabuaran Village, which is known as a religious village. It has 4 (four) places of worship originating from several religions in Indonesia. Not without reason, this is a step and proof of how different societies may lead to unity, in accordance with the country's motto. Based on the information the researchers acquired, residents and the government in Pabuaran Village agreed that differences were a natural thing and should be accommodated properly.

The village pillar is an important part in determining the success of the village in various sectors. The villagers tend to have the character of a producer as well as a consumer. They have strong capitals, namely, Natural Resources, Human Resources, a spirit of mutual cooperation and a desire for deliberation to reach mutual consensus. This is a timeless characteristic of Pabuaran villagers, as opposed to urban residents or urbanites who are mere consumers, and can get what they need (and want) instantly.

Natural resources remain in the development stage due to the lack of land, but the human resources in Pabuaran Village can be augmented without any maximum limit, in forms of tofu craftsmen and other factory products, which added to the strength of harmony within the village. Livelihoods may vary, but local entrepreneurial instincts are still prioritized. Currently, there are 16 existing and surviving entrepreneurs. The main goal is to maximize the goods distribution, hence food products are not taken over unilaterally by irresponsible outsiders. The role of local entrepreneurs for the residents is also large, specifically to provide employment to the community.

The social and economic side are have always been a concern for this village. Recently, the concern is shifting to the education side, where the local teachers' potentials are still being improved. The local government is providing a solution for the less fortunate locals, by creating the "Happy Schools, Happy Learning Program" (Program Senang Sekolah, Senang Belajar). This program was created to increase the local'sinterest in learning, as well as a platform of sharing from facilitators in Pabuaran Village. The former Head of Pabuaran Village, Mad Aidin also wish that this program may increase locals' knowledge in English and Mandarin. He also wish to open libraries and more schools.

Another thing that is simple but also worth discussing is from a cultural perspective. Some of the routine cultures exhibited at Pabuaran Village include the Cultural Festivals, Lenong Performance, and Jaipongan Dance. In addition, yearly routine events such as the Republic of Indonesia's Anniversary Local Championship (football, badminton, and village gate decoration competitions) and Youth Pledge Day Celebration (Healthy Walk Action) are celebrated. There is no specific hereditary tradition for villagers, but they often attend various Holy Days (Hari Raya) events to appreciate their harmony in diversity.

The spirit of mutual cooperation and deliberation is the strength of the villagers. This is what the village leaders are aiming for by promoting discussions with residents in decision making. This proves the existence of the Indonesia's Five Main Principles, Pancasila, which is held by the people of Pabuaran Village. In the first principle, Believe in the One Supreme God (Ketuhanan yang Maha Esa), it can be seen how the residents of Pabuaran Village rely on the existing natural resources to meet their daily needs, even though the natural resources in Pabuaran Village is also remain limited, such as water use. In the second principle, Just 
and Civilized Humanity (Kemanusiaan yang Adil dan Beradab), it can be seen how the people of Pabuaran Village rely on one another. Pabuaran Village relies heavily on the results of human resources to meet their daily needs, such as tofu which are distributed to Depok and Bogor, sales of local crackers, cassava chips, and lanterns from 03 Area. The third principles, The Unity of Indonesia (Persatuan Indonesia), is seen from the nature of mutual cooperation which remains strong in Pabuaran Village. The fourth principle, Democracy led by the wisdom of deliberations among representatives (Kerakyatan yang Dipimpin oleh Hikmat Kebijaksanaan dalam Permusyawaratan Perwakilan), can be seen how the Village of Pabuaran consults, by holding discussions with local residents. And the fifth principle, Social Justice for Indonesians (Keadilan Sosial bagi Seluruh Rakyat Indonesia), is definitely observable from integrity towards various religion, by the people of Pabuaran Village. Periodically gathering has also become a strengthening aspect for Pabuaran Village.

Turning back to January 2018, the first time Pabuaran Village was named the Golden Village (Desa Emas). This is driven by the government's attention in terms of its governmental capacity and the large number of residents who have permanent jobs to earn income in the village. This feasibility is further strengthened by the title as Village of Harmony based on the the Ministry of Tourism's esearch and Development Survey.

The success in obtaining this special title was also balanced by the formation of the Forum for Religious Harmony (Forum Kerukunan Umat Beragama / FKUB), from the top to bottom layer of the residents. Therefore, the Tourism Village of 02 Hamlet, Cikoleang Village, Pabuaran Village was sparked. 02 Hamlet intersects with 01, it is marked by a lake (natural tourism) which can be used as a tourist attraction. 02 Hamlet is also close to local industry, which is the tofu industry.

According to the treasurer of Pabuaran Village, Asep, the religious village appeared unintentionally, from their ancients. The diversity of religions, including Islam, Christianity and Catholicism, and Confucianism. Even though there are not many, there are also people of Indian descent so they have the Sikh religion. Religious beauty and harmony are the key values that ultimately lead to developments in other sectors. Residents admit that they work together regardless of their religion to increase and strengthen the economy, while simultaneously maintain the relationship.

In accordance with the religion adopted, Pabuaran Village also has various places of worship professed by its residents. There are mosques, prayer rooms, churches and Sikh houses of worship. All of these places are designated for worship, but some have shifted to become religious tourism sites, such as ancestral graves in a strategic position, near Cisadane to be precise. The natural panorama adds to the existence of this village as a place worth visiting for tourists, including the lake stretching out in RW 01 and RW 02.

In general, village administration has been regulated in a law whereby the village government and Village Consultative Agency (Badan Pemusyawaratan Desa / BPD) are assisted by several other institution. In general, villages are required to have six institutions, namely Community Empowerment Agency (Lembaga Pemberdayaan Masyarakat / LPM), Family Welfare Agency (Pemberdayaan Kesejahteraan Keluarga / PKK), Youth Agency (Karang Taruna), Local Health Center (Posyandu), Neighbourhood Community (Rukun Tetangga / RT) and Hamlet (Rukun Warga / RW). In order to increase the Religious Community harmony in Pabuaran Village, the Indonesian central and regional governments 
are formed downward synergy through the Ministry of Religion, in which administrators also has been receiving special training provided by the government.

\section{Pabuaran Village Organization Communication}

Carrying out organizational functions shall be maximized by the entire elements of the village. It is a challenge for Pabuaran Village when the current structure has not yet fully established. RT and RW should be able to become independent agencies, however, due to lack of "literacy" in organizations, those are not yet functioned.

The research team conducted interviews with village officials who played a major role in determining Pabuaran Village as the Golden Village, including Mad Aidin (Village Head 2009 - 2019), Mad Usin (2020-2025), and Asep (Secretary 2020-2025). The village officials emphasized that the organization does not differentiate officials' religion or ethnicity and race. Despite having the majority of the population and members of the Islamic faith in the organizational structure, there are still opportunities for other religions officials to contribute. This is evidenced by the presence of Confucians who once held positions there, although in the end they resigned for personal reasons. The representtive who becomes the village officials is determined by prerogative rights of the village head, so there is no specific key guide regarding the village officials' religion.

The most common communication flow is downward communication. Davis in the book Wayne Pace and Don F. Faules, mentioned downward communication in an organization means that information flows from positions of higher authority to those of lower authority. In this case we see that there is communication between the Village Head and other village administrators, as well as by conducting deliberations. So that the decisions taken are in accordance with mutual agreement (Pace \& Faules, 2010).

As a form of prioritizing the harmony of the various religions in Pabuaran Village, an association was formed, or commonly known as the Pabuaran Village Harmony Association (Paguyuban Kerukunan Desa Pabuaran / PKDP) as an Institution. There are still a few flaws when there is no legitimate Village Head Regulation itself. But as long as it is in line with the principle of togetherness of Pabuaran Village and does not conflict with the structure of the village management, it is guaranteed that relationship is maintained. This is manifested for example by not prioritizing only religious teachers from the Islamic religion, but also teachers of other religions, therefore values of harmony, friendship, and mutual cooperation are neatly intertwined.

As a guide in improving the performance of the village and its instruments, mediation and submission of suggestions is very possible. The local suggestions was accepted directly by the Village Head, for which a team was sought after in the discussion. The results of village meetings are reviewed by the Village Head by looking at 5 criteria, namely Village Development, Governance, Education, Empowerment, and Unexpected Events.

\section{Pabuaran Village Development Plan}

The success of a village will not be reached without the participation of its citizens, from all elements, including the officials to young people, who may be underestimated. As a form of willingness to improve the village's performance, there is a strong desire to increase interest through social media which is popular today. The existence of social media today is 
undeniably one of the triggers for the success of a place to be well known to the public. Although there is already a special department that manages the village website, namely the People's Welfare Section, the echoes of Pabuaran Village are remain unheard.

The desire to proceed with development is abundant from within the village, but there are many challenges arise, infrastructure, public transport and budget are some of the main obstacles. There are some privately owner area which restrain the Pabuaran Village development. Therefore, Pabuaran Village is not able to progress due to its limited by ownership of land, roads and other infrastructure.

Another road map on the agenda is the development of village officials (members of the Institute and residents). However, this plan had not yet happened because there was no budget. Furthermore, there is confusion within village officials regarding the exact direction to be aimed. In order to overcome this obstacle, a CBT (Community Based Tourism) concept is needed, which is a concept where to maximize the positive impact of economic growth, social welfare, maintenance of local culture, and empowerment of a community's nature, by actively involving the people of the region. (ASEAN, 2016). This concept focuses on empowering community businesses and small communities to develop their domicile areas using their unique resources. With the implementation of this concept, it is hoped that Pabuaran Village can become an independent village by managing natural resources, human resources, infrastructure and maintaining existing local wisdom.

\section{CONCLUSION AND SUGGESTION Conclusion}

Nowadays Indonesian tourism is growing rapidly in various regions, including villages, where this helps economic equality and community welfare. One model of tourism development that has now been promoted by the Ministry of Tourism is the Tourism Village which prioritizes increasing resource potential through the maintenance of local wisdom to have a positive impact on the community. The application of the concept of Community Based Tourism (CBT) aims to help communities develop without losing their identity (Ahsani, Suyaningsih, Ma'rifah \& Aerani, 2018).

Development and long-term planning of Pabuaran Village may increase the potential of natural resources and natural resources that attract tourists to visit Pabuaran Village. One of the techniques to increase the potential is to expand the sale of factory products and increase this local wisdom with the key as EMAS Village, Harmony Village, and Religious Village.

The local wisdom inherent in the community, namely the principle of togetherness and peace, can be seen from the potential, organization, and planning of Pabuaran Village. This cannot be separated from the organizational structure, this must be considered because cooperation as a liaison between village residents and the government must be upheld. The goal of the village officials is to craft Pabuaran Village as an independent village with optimal infrastructure development.

\section{Suggestion}

Organizational model and tourism may improve the performance of the tourist objects to further promote the nation. Problems are unavoidable, such as organizational and technological literacy, infrastructure, inadequate human resources, to individual motivation. 
It is undeniable that the economy becomes the main form in regulating the cycle of the village. Developments need to be carried out, such as increasing production output in tofu factories, raising chickens, and receiving tourists with qualified coordination requirements. Cooperation between villages and development centers is also feasible.

In the infrastructure sector, facilities are need to be adequate, especially the development of information houses, souvenir shops, guest house, local culinary tours), and the provision of Tour Guide for tourists. Moreover, the cleanliness of the environment must be maintained.

Evaluation is crucial to be discusses within officials and residents to manage future constraints and finding the solutions together, thus there is no feeling of resentment and "halfheartedness" in carrying out village aims.

The concept of CBT (Community Based Tourism) will make Pabuaran Village an independent village. Therefore, it would be best if this concept can be implemented continuously. By making Pabuaran Village into an independent religious village, it is hoped to attract tourists to Pabuaran Village and the economy of Pabuaran Village may also elevated.

\section{REFERENCE}

Ahsani, R. D. P., Suyaningsih, O., Ma'rifah, N., \& Aerani, E. (2018). Penerapan konsep community based tourism (CBT) di desa wisata candirejo borobudur mewujudkan kemandirian desa. Publisia: Jurnal Ilmu Administrasi Publik; Vol 3, No 2 (2018): Oktober. Retrieved from http://jurnal.unmer.ac.id/index.php/jkpp/article/view/2270

ASEAN. (2019). ASEAN COMMUNITY BASED TOURISM STANDARD. Retrieved from https://www.asean.org/storage/2012/05/ASEAN-Community-Based-Tourism$\underline{\text { Standard.pdf }}$

Bungin, B. (2007) Metode Penelitian Kualitatif. Jakarta, Kencana Prenada Media 2015. Komunikasi Pariwisata: Brand and Destination. Prenada Media Group. Jakarta.

Denzin, N. K, \& Lincoln, Y. S. (1994). Handbook of Qualitative Research. Sage Publications, Inc. California.

Hadiwijoyo, S. S. (2012). Perencanaan Pariwisata Pedesaan Berbasis Masyarakat (Sebuah Pendekatan Konsep) (1st ed.). Yogyakarta: Graha Ilmu.

Harris, T.E. (2002) Applied Organizational Communication: Principles and Pragmatics for Future Practice. London, Lawrence Erlbaum Associates.

Kementrian Pariwisata Indonesia. (2019). Pengembangan Desa Wisata Berbasis Pendampingan Melalui Perguruan Tinggi. Jakarta.

Kriyantono, Rakhmat. 2007. Teknik Praktis Riset Komunikasi. Kencana Prenada Media Group. Jakarta.

Littlejohn, S.W. \& Foss, K.A. (2009) Teori Komunikasi. Jakarta, Salemba Humanika 
Pace, R.W. \& Faules, D.F. (2010) Komunikasi Organisasi: Strategi Meningkatkan Kinerja Perusahaan. Deddy Mulyana (ed.). Bandung, Remaja Rosdakarya.

Pemerintah Provinsi Jawa Barat. (2016, April 4). Desa Emas Terobosan Pembangun Desa. Retrieved from http://jabarprov.go.id/index.php/news/17000/Desa_Emas_Terobosan_Pembangunan_ $\underline{\text { Desa }}$

Putra, A. M., Aryanti, N. N. S., Astina, I. B. K., \& Setiawan, I. B. D. (2019). PENGEMASAN KULINER LOKAL DAN CINDERAMATA LOKAL DALAM MENDUKUNG PENGEMBANGAN DESA WISATA TISTA, KECAMATAN KERAMBITAN, KABUPATEN TABANAN. Sekolah Tinggi Pariwisata Triatma Jaya; Vol 9 No 1 (2019): JURNAL Perhotelan Dan Pariwisata Januari-Juni 2019. Retrieved from http://triatmajaya.ejurnal.info/index.php/triatmajaya/article/view/109

Spradley, James P. (2006). Metode Etnografi. Yogyakarta: Tiara Wacana

Syafi'i, M., \& Suwandono, D. (2015). Perencanaan Desa Wisata Dengan Pendekatan Konsep Community Based Tourism (CBT) Di Desa Bedono, Kecamatan Sayung, Kabupaten Demak. Ruang, 1(2), 51-60. https://doi.org/10.14710/RUANG.1.2.61-70

Triambodo, S., \& Damanik, J. (2015). ANALISIS STRATEGI PENGUATAN KELEMBAGAAN DESA WISATA BERBASIS EKONOMI KREATIF (Studi di Desa Wisata Kerajinan Tenun Dusun Gamplong, Desa Sumberrahayu, Kecamatan Moyudan, Kabupaten Sleman, DIY) (Universitas Gadjah Mada). Retrieved from http://etd.repository.ugm.ac.id/index.php?act=view\&buku_id=79364\&mod=penelitia n_detail\&sub=PenelitianDetail\&typ=html 